\title{
A Comparison of Information and Communication Technology Application in New Partnership for Africa's Development (NEPAD) and Non-NEPAD Schools in Kenya
}

\author{
Mildred A. Ayere, Florence Y. Odera, and John Agak \\ Maseno University, Kenya \\ ayeremildred@yahoo.com; Odera Florence@yahoo.co.uk; \\ John.Agak@gmail.com \\ Executive Summary
}

To date, less than ten percent of secondary schools in Kenya offer computer studies as a subject in the curriculum despite its perceived role in the nation's socio-economic development. The few schools that have an Information Communication Technology (ICT) programme limit the number of candidates who take up the subject, considering it a specialty despite its being an essential subject as other compulsory subjects like Mathematics and Languages. The ideal situation would be to have ICT mainstreamed in all school subjects such that it would be integrated in Geography, History, Commerce, Physics, etc. The New Partnership for Africa's Development (NEPAD) programme was expected to integrate ICT in all subject areas and to empower the school community with ICT skills. The government decided to use six schools in the NEPAD programme instead of expanding the provision of computers to more secondary schools in the country. It appears that the NEPAD schools project was given preference over all the other ICT programmes in the country then. It was therefore necessary to investigate the reasons for the preferential treatment. As a result this study sought to compare ICT application areas in NEPAD and non-NEPAD schools in Kenya in order to gauge the value of the new programme. The study used a combination of descriptive survey and ex-post-factor design to compare areas of ICT application in the two categories of schools. The findings indicated a significant difference in ICT application areas in NEPAD and non-NEPAD schools. Specifically, learners in NEPAD schools (Mean $=6.65+0.360$ ) posted a higher mean grade than their non-NEPAD (Mean=5.70+0.297) counterparts in the Kenya Certificate of Secondary Education (KCSE) examinations. However, the professional qualification of teachers in NEPAD and Non-NEPAD schools was not significantly different. The results of the study could provide the ministry of education with documentary evidence of the contributions of the NEPAD program to ICT education and the viability of implementing a similar program in all Kenyan secondary schools, especially through the involvement of the private

Material published as part of this publication, either on-line or in print, is copyrighted by the Informing Science Institute. Permission to make digital or paper copy of part or all of these works for personal or classroom use is granted without fee provided that the copies are not made or distributed for profit or commercial advantage AND that copies 1) bear this notice in full and 2) give the full citation on the first page. It is permissible to abstract these works so long as credit is given. To copy in all other cases or to republish or to post on a server or to redistribute to lists requires specific permission and payment of a fee. Contact HPublisher@InformingScience.orgH to request redistribution permission. sector players. It could further contribute to the advancement of knowledge about ICT curriculum development in Kenya

Keywords: NEPAD, ICT Project, eSchools, Application, Compare, Secondary schools 


\section{Introduction and Literature Review}

The New partnership for Africa's Development (NEPAD) was a combined project of the United Nations and the World Bank, which aims at developing an integrated socio-economic framework for Africa's renewal (Ogule, 2009; Oracle, 2005; Tilvawala, Myers, \& Andrade, 2009). Its three main areas of operation include economic, educational and social dimensions (NEPAD, 2005; Oracle, 2005). NEPAD's aim was to have Africans develop home-grown solutions to the continent's problems of poverty, illiteracy, and disease. Infrastructure, especially Information and Communications Technologies (ICTs), was identified as a key priority action area in order to promote conducive conditions for education and sustainable development (NEPAD, 2005). To fulfill the continent's ICT objectives, the NEPAD e-Africa commission was tasked to develop and implement the NEPAD ICT programme. Among the ICT high priority projects identified by the commission's headquarters in South Africa was the NEPAD e-school initiative (or NEPAD ICT Pilot Schools Project).

The NEPAD e-school initiative is a multi country, multi stakeholder initiative that was intended to impart ICT skills to young Africans in both primary and secondary schools in order to improve the quality of education and to bring information closer to the people (AbdulSamad, 2006; Ogule, 2009; Pring, 2009). NEPAD (2005) explains that it is a multi stakeholder because it involves different private companies in the ICT sector willing to partner with each participating country.

During the conceptualization stage, demonstration or piloting was introduced as a crucial initial step in the implementation of this program (NEPAD, 2005; Tilvawala et al., 2009). Six schools from each participating country were selected for piloting the project (Oracle, 2005; Tilvawala et al., 2009). According to Oracle (2005), the participating schools in Kenya were Maranda Boys (Nyanza province), Vihiga Boys' (Western province), Menengai High (Rift valley), Wajir Girls (North eastern), Mumbi Girls (Central province), and Isiolo Girls' (Eastern province).

NEPAD's project team further explained that Kenya's Ministry of Education, Science and Technology (MOEST), in partnership with three companies (Microsoft Corporation, Oracle Corporation, and Digital Satellite Television (DSTV)), would carry out the program implementation in Kenya. Microsoft sponsored the programmes in Maranda, Vihiga, and Wajir Girls while Oracle (2005) sponsored the programmes in Mumbi, Isiolo, and Menengai high schools. According to the Ministry of Education (2006), the schools were to provide infrastructure to be used while each company was to provide the kit for hardware and the software. DSTV provided to all the schools a satellite dish, 20" Television (T.V), videocassette recorder, and satellite decoder as well as a Very Small Aperture Terminal (V-SAT) system for Internet access via the African Computer Services Centre in Nairobi. Within the school, each classroom was to have a computer served from the laboratory for the teacher's use. Besides the kits, Microsoft and Oracle were also mandated to train the teachers in the Kenyan schools on how to adapt these programmes.

Earlier on, in 1996 the government, through MOEST, declared that all secondary schools should introduce computer studies. It was not clear how schools were to acquire the computers; as a result most schools failed to comply (Odera, 2002). The government in the same year approached UNESCO to fund its computer education programme. UNESCO responded by not only supplying some national schools with computers, but also trained the principals and a few of the teachers to start off the programme. To date less than ten percent of secondary schools offer computer studies despite its perceived role in the nation's socio-economic development (Avgerou, 2003; Okuogo, 2006; Sahlfeld, 2009; Weiner \& Rumiany, 2007). The few schools that had an ICT programme, limited the number of candidates who could take up the subject, considering it a specialty despite its being an essential subject as are compulsory subjects like Mathematics and Languages. The ideal situation would be that ICT is mainstreamed in all school subjects such that it would be integrated in Geography, History, Commerce, Physics, etc. According to Rodrigo (2003), this 
would bring out the threefold usage of ICT - as objects of study, as support tools, and as catalysts for learning.

The NEPAD programme was expected to integrate ICT in all subject areas and to empower the school community with ICT skills (Ogule, 2009; Tilvawala et al., 2009). The government decided to use six schools instead of expanding the provision of computers to more secondary schools in the country. It appears that the NEPAD schools were being set as experimental centers of excellence in ICT education so that other schools could copy their model (MOEST, 2005). To gauge their success as centers of excellence there was need to survey their activities and provide information on the same. Therefore this study sought to compare ICT application areas in NEPAD and non-NEPAD schools in Kenya as a means of verifying these claims.

A previous study by Kinyanjui and Nderitu (2005) through UNESCO noted the value of ICT integration in education. They explained that integration involves the fusing of both technology and pedagogy in different measures that allow for students' exploration during learning. As such, the government encouraged the private sector to assist in the promotion of ICT in secondary schools (Wafula \& Wanyonyi, 2007). This led to a number of bodies financing ICT in public schools. Okutta (2007), Krige and Okono (2007), and Wangari (2008) noted that the financing partners included Computer for Schools Kenya, Kenya Education Network, the ICT Trust Fund, and NEPAD. Farrell, Isaacs, \& Trucano (2007) pointed out that the NEPAD project was multinational, multidimensional and also multisectorial in nature, making it appealing to governments. The nonNEPAD programmes on the other hand were funded through Parents Teachers Associations (PTAs) and Boards of Governors (BOGs) (Wafula \& Wanjohi, 2007).

Geisert and Furtell (2000) pointed out that ICT is useful in the teaching process, while Sadker and Sadker (2000) and McNamara (2003) all reported that the other ICT application areas in education were administration, record keeping, computer literacy, education research, assistive technologies, and a source of employment. At the same time, Shrum and Dehoney (1998) noted that teachers who were computer literate used the technology to publish their work, create videos, design portfolios, communicate, and develop professionally through the use of the Internet.

Despite the potential of technology, Tilya (2007) reported that the main factor affecting ICT application areas in a school was leadership. Education Insight ("ICT set up in schools," 2006), Okuogo (2006) and Wangari (2008) highlight other factors affecting use of ICT in a school as high cost of equipment, teachers' ICT literacy status, school ICT policy, type of sponsor for the programs, and the hardware available in a school.

The other important factor that hinders the implementation of technology is lack of trained manpower. Tilya (2007) stated that the development of any country depends very much on the level of education of its citizens. Batchelor and Nocrish (2005) explained further that many governments were using the introduction to ICT as a way of providing teachers with new skills and introducing new pedagogy into the classroom.

\section{The Purpose of the Study}

The purpose of this study was to find out the impact of ICT in NEPAD and non-NEPAD schools by comparing ICT application areas in education and development. The main objectives that guided the study were to examine the ICT human resource level and training available in NEPAD and non-NEPAD schools. It also sought to identify the ICT equipment and material resources available for use in NEPAD and non-NEPAD schools. It compared significant ICT application areas in NEPAD and non-NEPAD schools. At the same time it identified factors that influence ICT application areas in NEPAD and non-NEPAD schools. Lastly, the study compared learner achievement in the KCSE examinations in NEPAD and non-NEPAD schools. 


\section{Research Questions}

This study was guided by the following research questions:

1. What ICT human resource levels and training are available in NEPAD and non-NEPAD schools?

2. What ICT equipment and materials resource are available in NEPAD and non-NEPAD schools?

3. What were the significant differences in ICT application areas in NEPAD and nonNEPAD schools?

4. Which factors influenced ICT application areas in NEPAD and non-NEPAD schools?

5. Was there a significant difference in learner achievement in the KCSE examination in NEPAD and non-NEPAD schools?

\section{Conceptual Framework}

The conceptual framework used in this study was adapted and modified from the current situation analysis (CSA). The CSA is an equivalent of strength, weakness, opportunities and threats (SWOT) analysis (Oriwo 2002). Its aim was to guide this study by identifying the major problems in ICT education and the impact of ICT education and its infrastructure in the school and surrounding community. It further explored the possible factors affecting ICT application in a school and considered the possibility of using the NEPAD ICT programme in the school and the surrounding community as an intervention. Lastly, it considered the expected impact of the NEPAD ICT programme as an intervention. The diagrammatical representation of the conceptual framework is shown in Figure 1.

\section{Methodology}

\section{Research Design}

This study used a combination of an exploratory approach using descriptive survey and ex-postfacto design. These were used to compare ICT application areas in NEPAD and non-NEPAD schools in Kenya. According to Gall, Borg, and Gall (1996), a descriptive survey design is used in a preliminary and exploratory study to allow the researchers to gather information about the current status of the subjects under study. The subject under study in this case was the NEPAD pilot schools' project on ICT integration implemented through the NEPAD e-African commission in selected schools in Kenya. The ex-post facto design, according to Gay (1996) attempts to determine the cause or reason for existing differences in the status of groups where evidence exists before the study is done. In this case the researchers needed to compare performance of NEPAD and non-NEPAD schools by examining already existing documents in these schools.

\section{Study Location}

The study was carried out in six of the eight provinces in Kenya where the NEPAD schools are located. Precisely, the study area included Bondo District in Nyanza province where Maranda High School is located, Vihiga District in Western province where Chavakali High School is, Nakuru District in the Rift Valley where Menengai High is situated, Wajir District in North Eastern Province where Wajir Girls is located, Murang'a District in Central Province where Mumbi Girls is, and lastly Isiolo District in Eastern province where Isiolo Girls is located. 


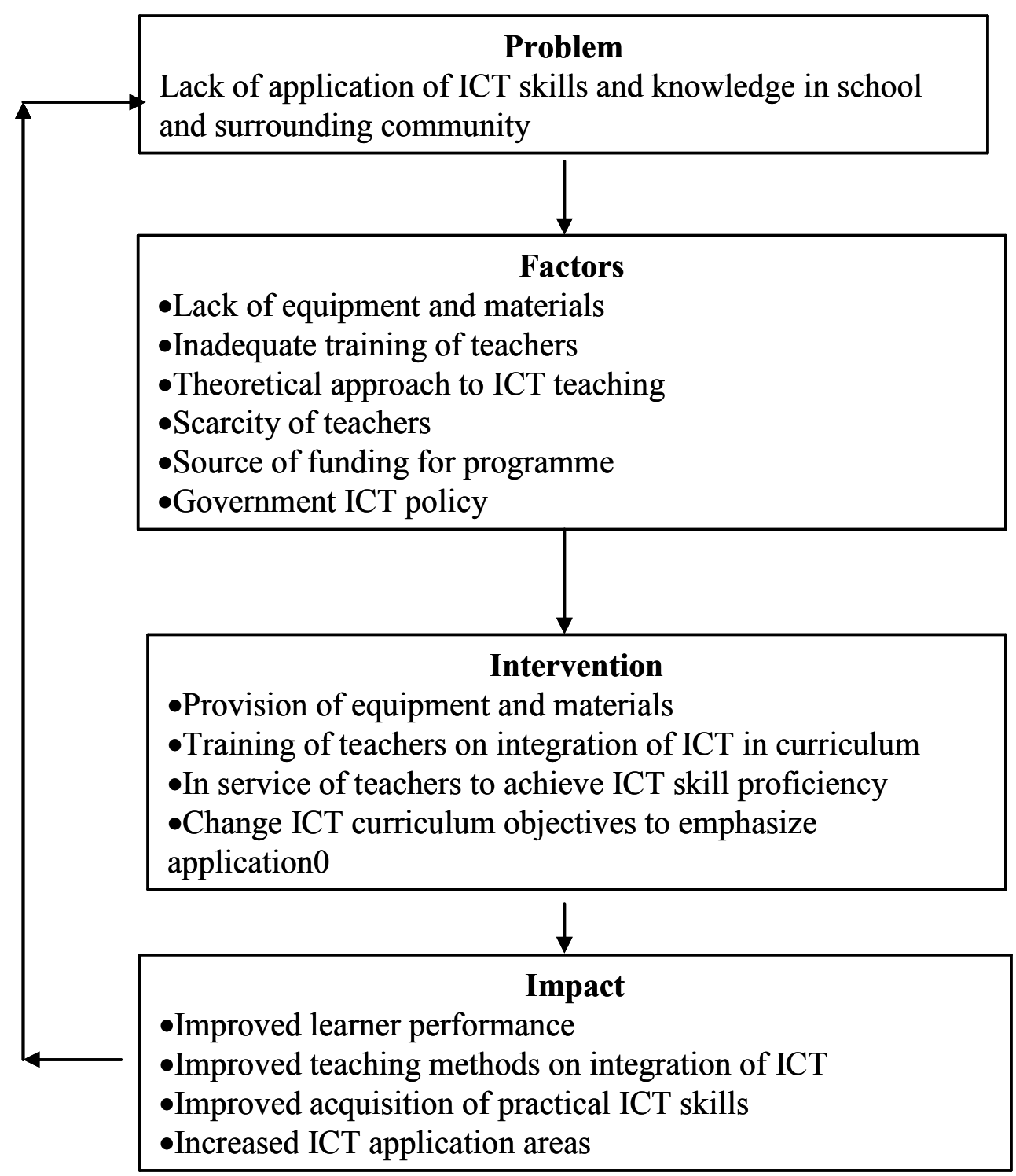

Figure 1. Conceptual framework of ICT application in NEPAD and Non-NEPAD schools

\section{Target Population}

The study targeted 1600 Form Four students from 35 secondary schools offering Computer Studies in the study districts. The 35 schools were distributed in the study districts such that 8 were in Vihiga, 2 in Isiolo, 3 in Wajir, 9 in Murang'a, 2 in Bondo, and 11 in Nakuru district, where the NEPAD schools are situated. Orodho (2004) explained that exploratory descriptive survey studies have two crucial categories of respondents, namely, the informed specialists and the consumers. Consequently this study targeted four quality assurance personnel in charge of Computer Studies at the Ministry of Education, Science and Technology (MOEST) headquarters, three computer studies subject personnel at the Kenya Institute of Education (KIE), and the two representatives from NEPAD secretariat, namely, the national liaison person at the head office and the school representative, all of which formed the specialist category. The consumer category included the 36 schools' principals, 36 heads of ICT department in the study schools, and the 1600 Form Four students in all the schools within the population. 


\section{Sample and Sampling Procedure}

The schools were used as sampling units, and saturated sampling was done for the NEPAD schools. At the same time simple random sampling was employed for the non-NEPAD schools to select 6 equivalent non-NEPAD schools. This was done except in special instances where it was necessary to randomly choose a school after matching its obviously skewed features. For example, where the NEPAD School was mixed day then it was necessary to confine sampling of nonNEPAD schools to mixed day schools. This helped to reduce the effects of the intervening variables. The sample, therefore, consisted of three specialist personnel, namely, one subject specialist from KIE, the national Quality Assurance and Standards personnel in charge of Computer Studies, and the NEPAD national liaison person. The consumer category consisted of the twelve principals from the study schools (6 NEPAD and 6 non-NEPAD), twelve ICT HODs, and 570 Form Four students in the study schools. It should be noted that out of 570 students sampled for the study only 384 returned their questionnaires, representing a 67 percent return rate. At the same time, all the 12 principals, and all the 12 HODs returned their questionnaires, representing 100 percent returns.

\section{Data Collection Instruments}

The study instruments consisted of questionnaires, interview schedules, and observation checklists. The questionnaires were administered to the students, the principals, and the teachers. The interview schedules were administered to the national quality assurance personnel in charge of Computer Studies, the KIE Computer Studies' specialist, and the NEPAD national liaison person. Meanwhile the researchers used the observation checklist to confirm the information gathered through the questionnaires from all the 12 study schools.

\section{Reliability and Validity}

This study used the test-retest (coefficient of stability) method to estimate the degree of reliability of the instruments. Spearman's rank order correlation was employed to compute the coefficients of reliability. The computed coefficients were approximately $0.79,0.82$, and 0.87 for the students, teachers, and the principals' questionnaires respectively. Reliability was further enhanced by triangulation where the same facts were elicited for from different people in the same setting. The study further relied on content validity procedures using two sets of experts. These experts gave their views on the comprehensibility, relevance, and clarity of the set questionnaire items. All the questionnaires, interview schedules, and checklists were subjected to this treatment. All the experts then provided feedback, and their recommendations were incorporated in the final instruments used in this research.

\section{Data Collection Procedures}

The questionnaires were taken to each of the schools by the researchers except for Wajir Girls and Sabunley Boys where the questionnaires were sent online to the teachers. Due to the time of year (October), all the schools requested to be left with questionnaires for students, which were completed and mailed back to the researchers. The questionnaires for principals and teachers were filled in and carried away by the researchers.

\section{Method of Data Analysis}

The data collected were analyzed using descriptive statistics (frequencies, percentages, and means) and inferential statistics (correlation coefficients, analysis of variance (ANOVA), and chisquare). The information collected through the questionnaires, interview schedules, and checklists 
were tabulated using frequency counts and percentage tables with the help of a computer package (Statistical Package for Social Sciences or SPSS).

\section{Results}

To carry out meaningful analysis, the information from the study schools' administrators, ICT teachers, and students were analysed using SPSS and recorded in tables. These responses were verified by the responses from the interviews of the KIE subject specialist in Computer Studies, the national quality assurance personnel at MOEST in charge of computer education, and the NEPAD national liaison person. Further verification of the information was done using the checklist. All these pieces of information were consolidated to bring out the results of the research (see Table 1), which are presented in the remaining parts of this report in an attempt to answer the research questions. To identify significant differences in the outcomes in NEPAD and non-NEPAD schools, further analysis was carried out using SPSS to work out ANOVA, Chi-square, and Pearson correlation measures. A summary of these results are presented in Table 1 and discussed in the sections that follow.

Table 1. Summarised Research Results

\begin{tabular}{|c|c|c|c|c|}
\hline No. & Summarized Result Item & Rating Scale (\%) & $\begin{array}{l}\text { NEPAD } \\
\text { Schools }\end{array}$ & $\begin{array}{l}\text { Non-NEPAD } \\
\text { Schools }\end{array}$ \\
\hline 1. & $\begin{array}{l}\text { ICT teachers' qualifications } \\
\left(N_{1}=21 \text { and } N_{2}=9\right)\end{array}$ & $\begin{array}{l}\text { Certificate } \\
\text { Diploma } \\
\text { Degree }\end{array}$ & $\begin{array}{l}33 \\
14 \\
53\end{array}$ & $\begin{array}{l}11 \\
56 \\
33\end{array}$ \\
\hline 2. & $\begin{array}{l}\text { Teachers' ICT literacy status } \\
\left(N_{1}=228 \text { and } N_{2}=204\right)\end{array}$ & $\begin{array}{l}\text { Male } \\
\text { Female } \\
\text { Literacy ratio }\end{array}$ & $\begin{array}{l}44 \\
16 \\
60\end{array}$ & $\begin{array}{l}22 \\
9 \\
30\end{array}$ \\
\hline 3. & $\begin{array}{l}\text { ICT integration in the teach- } \\
\text { ing/learning process } \\
\left(N_{1}=190 \text { and } N_{2}=194\right)\end{array}$ & $\begin{array}{l}\text { Humanities } \\
\text { Sciences } \\
\text { Languages } \\
\text { Mathematics }\end{array}$ & $\begin{array}{l}87 \\
100 \\
100 \\
100\end{array}$ & $\begin{array}{l}17 \\
50 \\
17 \\
17\end{array}$ \\
\hline 4. & $\begin{array}{l}\text { Use of ICT in education research } \\
\left(N_{1}=190 \text { and } N_{2}=194\right)\end{array}$ & $\begin{array}{l}\text { All } \\
\text { Many } \\
\text { Some } \\
\text { Few } \\
\text { None }\end{array}$ & $\begin{array}{l}\mathbf{1 7} \\
\mathbf{3 3} \\
\mathbf{5 0} \\
\mathbf{0} \\
\mathbf{0}\end{array}$ & $\begin{array}{l}0 \\
0 \\
17 \\
17 \\
66\end{array}$ \\
\hline 5 . & $\begin{array}{l}\text { Use of Internet services } \\
\left(N_{1}=190 \text { and } N_{2}=194\right)\end{array}$ & $\begin{array}{l}\text { Daily } \\
\text { Weekly } \\
\text { Monthly } \\
\text { Termly } \\
\text { Never }\end{array}$ & $\begin{array}{l}30 \\
63 \\
2 \\
4 \\
1 \\
\end{array}$ & $\begin{array}{l}1 \\
5 \\
3 \\
1 \\
90 \\
\end{array}$ \\
\hline 6. & $\begin{array}{l}\text { Availability of e-libraries } \\
\left(\mathrm{N}_{1}=40 \text { and } \mathrm{N}_{2}=3\right)\end{array}$ & Total number & 93 & 7 \\
\hline 7. & $\begin{array}{l}\text { Frequency of access to online educa- } \\
\text { tional materials } \\
\left(N_{1}=190 \text { and } N_{2}=194\right)\end{array}$ & $\begin{array}{l}\text { Many } \\
\text { Some } \\
\text { Few } \\
\text { None }\end{array}$ & $\begin{array}{l}\mathbf{5 0} \\
\mathbf{5 0} \\
\mathbf{0} \\
\mathbf{0}\end{array}$ & $\begin{array}{l}0 \\
16 \\
16 \\
68\end{array}$ \\
\hline
\end{tabular}




\begin{tabular}{|c|c|c|c|c|}
\hline No. & Summarized Result Item & Rating Scale (\%) & $\begin{array}{l}\text { NEPAD } \\
\text { Schools }\end{array}$ & $\begin{array}{l}\text { Non-NEPAD } \\
\text { Schools }\end{array}$ \\
\hline 8. & $\begin{array}{l}\text { Use of e-mail services } \\
\left(N_{1}=190 \text { and } N_{2}=194\right)\end{array}$ & $\begin{array}{l}\text { Daily } \\
\text { Weekly } \\
\text { Monthly } \\
\text { Termly } \\
\text { Never }\end{array}$ & $\begin{array}{l}29 \\
47 \\
5 \\
10 \\
9\end{array}$ & $\begin{array}{l}0 \\
5 \\
2 \\
1 \\
92\end{array}$ \\
\hline 9. & $\begin{array}{l}\text { Access to e-learning materials } \\
\left(N_{1}=190 \text { and } N_{2}=194\right)\end{array}$ & $\begin{array}{l}\text { Many } \\
\text { Few } \\
\text { None } \\
\end{array}$ & $\begin{array}{l}100 \\
0 \\
0 \\
\end{array}$ & $\begin{array}{l}0 \\
33 \\
67\end{array}$ \\
\hline 10. & $\begin{array}{l}\text { Schools' KCSE Mean grade } \\
\left(N_{1}=297 \text { and } N_{2}=273\right)\end{array}$ & Average mean & 6.65 & 5.70 \\
\hline 11. & $\begin{array}{l}\text { Schools' KCSE Computer Studies } \\
\text { mean grade }\left(N_{1}=297 \text { and } N_{2}=273\right)\end{array}$ & Average mean & 8.27 & 6.69 \\
\hline 12. & $\begin{array}{l}\text { Computer to learner ratio } \\
\left(N_{1}=4306 \text { and } N_{2}=4271\right)\end{array}$ & Ratio & $1: 14$ & $1: 35$ \\
\hline 13. & $\begin{array}{l}\text { Total in Range of ICT equipment } \\
\left(N_{1}=339 \text { and } N_{2}=140\right)\end{array}$ & Percentage & 71 & 29 \\
\hline
\end{tabular}

Key to Table 1: $\mathrm{N}_{1}=$ Total outcomes in NEPAD schools; $\mathrm{N}_{2}=$ Total outcomes in non-NEPAD schools

\section{Human Resource Levels and Availability}

The first research question from this study focused on the type of ICT personnel that were present in the NEPAD and non-NEPAD schools. Specifically the research question was: What ICT human resources were available in NEPAD and non-NEPAD schools? The human resource referred to both the teaching staff and the non-teaching staff.

Analysis in the area of human resource was done in terms of teachers' professional qualifications, teachers' ICT qualification, funding of teachers' ICT training, in-service of teachers, and teaching support staff availability and funding.

The results indicated that none of the study schools (both NEPAD and non-NEPAD) had ICT support staff.

Table2. Qualification and Average Number of Teachers in ICT Department

\begin{tabular}{lcccccc}
\hline Type of School & No. of teachers & $\begin{array}{c}\text { Average experience } \\
\text { (Yrs) }\end{array}$ & \multicolumn{5}{c}{ Qualification } \\
\hline & & & Cert & Dip & Tech & Degree \\
NEPAD & 21 & 6 & 7 & 3 & 0 & 11 \\
Non-NEPAD & 9 & 3 & 1 & 4 & 1 & 3 \\
\hline
\end{tabular}

Table 2 shows the checklist results which indicated that the teaching staff levels in the ICT department of the NEPAD schools (21 teachers in all) were much higher than that in the nonNEPAD schools (9 teachers in all). This was because three of the non-NEPAD schools had only one ICT teacher each, while the other three had only two ICT teachers each, giving an average of 1.5 ICT teachers per school. This was in contrast to the NEPAD schools where five schools had at least three ICT teachers each with the sixth school having a total of five ICT teachers, giving an average of 3.5 teachers per school. The non-NEPAD teachers had ICT qualifications ranging from Certificate (1), Diploma (4), Technical education (1), and Degree (3). While the NEPAD teachers had ICT qualifications ranging from Certificate (7), Diploma (3), Technical Education 
(0), and Degree (11). In terms of teachers' ICT qualifications, therefore, the NEPAD school ICT teachers had better qualifications (53\% had degrees compared to $33 \%$ from non-NEPAD schools), however this difference was not significant. The NEPAD schools had more ICT teachers, making their student to teacher ratio in ICT lower than that of the non-NEPAD schools (18:1 and 20:1 respectively). This may have had some impact on their learner performance in the ICT related fields. At the same time, more NEPAD school teachers (137) received in-service training in ICT as compared to only 62 teachers from the non-NEPAD schools. The mode of funding for these teachers was found to be mainly peer training $(47 \%)$ followed by personal sources $(35 \%)$, NEPAD (13\%), BOGs (3\%), and the government (1\%) in the NEPAD schools. In non-NEPAD schools, funding was mainly from teachers' personal sources $(94 \%)$ while BOG, government and NEPAD each contributed to the funding of only 2 percent of the teachers. This gave rise to teacher ICT literacy ratios to total teachers of 60 and 30 percent (Table 1) in NEPAD and non-NEPAD schools respectively.

\section{Availability of ICT Equipment}

The second objective of this study was to identify the ICT equipment and material resources available for use in NEPAD and non-NEPAD schools. To meet part of this objective, it was necessary to ascertain the type and amount of equipment for teaching ICT in the schools. The researchers used the checklist to record the existing ICT equipment in the study schools and the results are presented in Table 3.

Table 3. Numbers of ICT Equipment in the Study Schools

\begin{tabular}{lllllll}
\hline School & Computers & Laptops & Scanners & Printers & $\begin{array}{l}\text { LCD } \\
\text { projectors }\end{array}$ & $\begin{array}{l}\text { Smart } \\
\text { boards }\end{array}$ \\
\hline NEPAD & 298 & 1 & 8 & 23 & 6 & 3 \\
Non- & 123 & 1 & 3 & 13 & 0 & 0 \\
NEPAD & & & & & & \\
\hline
\end{tabular}

Table 3 shows that, in both categories of schools, the desktop computers were the most common equipment. The NEPAD schools had 298 computers, giving an average of 50 computers per school and a computer to learner ratio of 1:14 (Table 1). The non-NEPAD schools had 123 computers, giving an average of 20 computers per school and a computer to learner ratio of 1:35. It meant that on averagely every NEPAD school had more than twice the number of computers than in the non-NEPAD school. Apart from the laptop, NEPAD schools had almost double of every type of equipment than the non-NEPAD schools (Table 3). Further analysis indicated that the NEPAD schools had a total of 339 different pieces of ICT equipment within the six schools while the non-NEPAD schools had 229 pieces. This gave 60 percent and 40 percent rating in terms of total number of equipment within the range of ICT equipment in the two categories of schools respectively. In terms of variety, NEPAD schools had the full range of the six different types of equipment ( $100 \%$ in variety) found in the two categories of schools. The non-NEPAD schools on the other hand had four of them (67\% in variety). Considering the disparity in the total number of equipment within these varieties, the difference in total number and type of equipment in the two categories of schools was significant.

The other important finding of the study was that amongst the non-NEPAD schools only one out of the six schools had three different e-libraries (Table 1), all from one school sponsored by Computer for Schools, Kenya. In contrast all the NEPAD schools had 40 e-libraries, at least five in each school, with the leading school having fifteen different ones. The other fact worth noting was that only one non-NEPAD school had an Internet connectivity appliance, i.e. a blue tooth 
from a mobile phone provider. All NEPAD schools on the other hand had a V-SAT (Very Small Aperture Terminal) that enabled them to achieve Internet connectivity. It was therefore not surprising when further analysis through Chi-square revealed that there was a significant difference $\left(\chi^{2}=9.00, \mathrm{df}=3, \mathrm{p}<0.05\right)$ in the extent of achievement of access to online materials by NEPAD schools as compared to the non- NEPAD schools.

\section{Significant ICT Application Areas}

The third research question that needed to be answered in this section was: What were the significant differences in ICT application areas in NEPAD and non-NEPAD schools? The results indicated that the main significant ICT application area was in the integration of ICT in the teaching/learning process. The results (Table 1) indicated that the NEPAD schools integrated ICT in the teaching of Humanities at a rate of 87 percent while Languages, Mathematics and Sciences had 100 percent integration rates. In the non-NEPAD schools ICT was integrated at a rate of only 17 percent in Mathematics, Languages and Humanities, and at a rate of 50 percent in Sciences. These responses were analyzed further and results recorded in Tables 4 and 5.

Table 4. ANOVA for Integration of ICT in NEPAD Schools

\begin{tabular}{lcrrcc}
\hline Source & DF & SS & MS & F & P \\
Subject & 1 & 20.02 & 20.02 & 16.03 & 0.000 \\
Error & 46 & 57.46 & 1.25 & & \\
Total & 47 & 77.48 & & & \\
\hline
\end{tabular}

Table 4 shows that use of ICT in teaching other subjects in NEPAD schools was significantly more frequent, $(\mathrm{F}=16.03, \mathrm{df}=1, \mathrm{P}<0.05)$ than in the non-NEPAD schools $(\mathrm{F}=2.90, \mathrm{df}=1, \mathrm{P}$ $<0.05)$, see Tables 4 and 5. This could be explained by the fact that the NEPAD Schools had Internet services ( $100 \%$ of the schools), e-libraries ( $71 \%$ of the schools) and ICT equipment variety $(100 \%)$. As a result they had 100 percent access to online materials and 91 percent usage of email services (see Table 1).

Table 5. ANOVA for Integration of ICT in non-NEPAD Schools

\begin{tabular}{lccccl}
\hline Source & DF & SS & MS & F & P \\
Subjects & 3 & 13.50 & 4.50 & 2.90 & 0.060 \\
Error & 20 & 31.00 & 1.55 & & \\
Total & 23 & 44.50 & & & \\
\hline
\end{tabular}

Table 5 presents ANOVA results for the integration of ICT in non-NEPAD schools. It indicated that integration of ICT in non-NEPAD schools was not significant $(\mathrm{F}=2.90, \mathrm{df}=1, \mathrm{P}<0.05)$. It meant that where ICT was used in teaching in these schools, the impact was not significant enough to have an effect on teaching/learning process. This was due to the fact that Internet services, e-libraries, and ICT equipment were available at a rate of only 10 percent, 7 percent and 29 percent respectively (Table 1). As a result they had only 32 percent access to online materials and 8 percent usage of email services (see Table 1).

The other notable ICT application area investigated in this study was in education research. The results (Table 1) indicated that 100 percent of students from NEPAD schools used ICT in education research as compared to only 34 percent of students from non-NEPAD schools. This could be explained by the fact that the use of Internet services was indicated by 99 percent of students 
from NEPAD schools as compared to only 10 percent from the non-NEPAD school students. At the same time access to e-materials and other online materials was indicated by 100 percent of students from NEPAD schools but only 33 and 32 percent of students from the non-NEPAD schools. These findings were further confirmed by the fact that the NEPAD schools had more computers and a higher variety of other ICT equipment than the non-NEPAD schools. This therefore resulted in computer to student ratios of 1:14 and 1:35 in the two categories of schools respectively.

\section{Identification of Factors Influencing ICT Application Areas}

The fourth question that needed to be answered by this study was: Which factors influenced ICT application areas in NEPAD and non-NEPAD schools? This question was answered by using the students' rating of a list of factors that they felt influenced their usage of ICT in the individual schools. This was a combined analysis for students in both NEPAD and non-NEPAD schools. A large number of them (78\% of students) indicated that availability of computers was a major factor affecting their use of the computer laboratory. The other factors that were identified by the students included rules and regulations from the ICT department ( $48 \%$ of students); number of computer literate teachers in the school (47\% of students); school rules and regulations (35\% of students); school administration's policy on computer use ( $23 \%$ of students); regulations from the ICT funding bodies ( $20 \%$ of students); and the daily schedule of the school (10\% of students).

\section{Comparing Learner Achievement in NEPAD and Non-NEPAD Schools}

The fifth question that this study aimed at answering was: Was there a significant difference in learner achievement in the KCSE examinations in NEPAD and non-NEPAD schools? This question was answered by comparing the KCSE mean scores in the two categories of schools in terms of overall school mean grades as well as mean grades in the KCSE Computer Studies examination. The results from Table 1 indicated that the NEPAD schools posted a higher KCSE mean score of $6.65 \pm 0.360$ on average as compared to $5.70 \pm 0.29$ posted by the non-NEPAD schools. At the same time, the NEPAD schools average performance in the KCSE Computer Studies (8.27) was higher than the same result from the non-NEPAD schools (6.69). These differences in mean grades were subjected to a test of significance. The results indicated that the differences in the KCSE mean grades in the NEPAD and non-NEPAD schools were significant (ANOVA, F = $4.148, \mathrm{df}=1, \mathrm{P}<0.05)$. Further investigation indicated that the higher quantity and wider variety of ICT equipment and e-content available in the NEPAD schools may have had a significant positive impact on the schools' KCSE performance. In an attempt to establish the cause of the difference in performance, an analysis of the correlation of type of equipment to schools KCSE mean grade was done and as a result it was established that there was a positive correlation between the variety of ICT equipment available in a school and a school's performance in KCSE. The correlation analysis calculations indicated a significant positive relationship $(\mathrm{r}=0.421, \mathrm{df}=1)$ between the KCSE mean grade to variety of ICT equipment found in a school, the NEPAD schools having a much higher variety ( $71 \%$ compared to $29 \%$ for non-NEPAD schools). Further analysis was done with the help of ANOVA to confirm these results. The analysis revealed that the presence of a wider variety of ICT equipment in the NEPAD schools resulted in a significant improvement (ANOVA, $\mathrm{F}=7.131$, $\mathrm{df}=6, \mathrm{P}<0.05$ ) in the KCSE performance.

\section{Discussion}

The results from the study indicated that integration of ICT in teaching and learning was more significantly used in NEPAD schools as compared to non-NEPAD schools. This was because integration took place in all subject areas in all the NEPAD schools whereas little or no integra- 
tion took place in the non-NEPAD schools. This could be explained by the fact that the NEPAD schools had a higher number and a wider variety of ICT equipment like Internet, e-libraries, smart boards, LCD projectors, and DSTV services. The non-NEPAD schools on the other hand, did not have any of these. This was in line with sentiments expressed by Rodrigo (2003), LaPorte (2008), and Brown (2009) when they pointed out that funding of ICT resources determined the level of integration of ICT in the teaching/learning process. The results had further indicated that the non-NEPAD teachers (89\% with Diplomas and Degrees) had better ICT qualifications for the two groups combined than their counterparts in the NEPAD schools $(67 \%$ with Diplomas and Degrees). Despite this fact, the results indicated that the NEPAD schools were better able to integrate ICT into the curriculum. This finding could be explained by the fact that more teachers from the NEPAD schools were computer literate $(60 \%)$ as compared to their non-NEPAD counterparts (31\%). At the same time NEPAD schools had more ICT graduate teachers $(53 \%)$ than the nonNEPAD schools (33\%) The other reason identified during research for this difference was the fact that peer training was the main source of ICT literacy in the NEPAD schools, a concept which was lacking in the non-NEPAD schools. This result was supported by McCarthy and Berger (2008), Schifter (2008), Garvey (2009), and Sang, Valcke, Braak, \& Tondeur (2009) who all agreed that mentoring or role modeling is a highly motivating factor in propelling a schools' ICT integration. This does not mean that professionalism should be replaced by peer training or mentoring (Gobbo \& Girardi, 2001). Rather, professional training in ICT integration should have a practical component in which teachers with technology expertise and mentoring capabilities should be motivated to assist others in integrating technology (Eunjoo \& French, 2004; Ma, Lai, Williams, \& Prejean; 2008; Okuogo, 2006; Paechter, Maier, \& Macher, 2009; Zhao \& Bryant, 2009). This was what was done when four teachers were trained on integration from each NEPAD school irrespective of their area of subject specialization (Oracle, 2005). These four spearheaded the peer training on ICT integration in each NEPAD school. The success of integration in NEPAD schools, therefore, could be attributed to two main factors: the use of peer training in the project schools and provision of a wide variety of ICT equipment and services. These sentiments are in agreement with those expressed by Allison and Harbour (2009), and Hinterberger (2009).

The results of the study also indicated that 100 percent of NEPAD school students used ICT for education research while only 34 percent of the non-NEPAD school students had access to the same. This meant that there was a big difference in the way ICT was used academically in the two categories of schools and by extension its influence on academic performance of the schools (Friesen, 2009; Kioni, 2009). In this research, availability and use of the Internet, e-libraries, and email were used to gauge the differences in utilization of educational research in the two categories of schools. The study results indicated that there was a significant difference in Internet usage between NEPAD and non-NEPAD schools $\left(\chi^{2}=12, \mathrm{df}=3, \mathrm{p}=0.05\right)$. This was not surprising given that all the NEPAD schools had free Internet service and connectivity while only one of the nonNEPAD schools had the same facility and, even then, the students had to pay for the service by buying a mobile phone card for access. This fact is supported by Frederick and Shockley (2009) when they indicated that once learners are introduced to and given access to the Internet, they continue to make personal discovery which leads to self motivation. The main reason given for non-connectivity of schools in Kenya was not only the cost of Internet services but also the low level of development especially of communication infrastructure in the entire nation (Bonyo, 2008; Kenny, 2000; Kioni 2009; Wangari, 2008). This was because most schools in the rural areas do not have electricity and the cost of Internet has been very high. The government hopes this will come down drastically with the completion of the first under sea cable (Ongeri, 2009). The reduction in Internet cost, it is predicted, will make it possible for the government to connect nursery, primary, and secondary schools across each district with high speed wireless networks that will support increasing media-rich education tools (Kioni, 2009). Actually the major complaint from the NEPAD schools was interruption/slow connectivity because NEPAD Internet 
broadband width was very small (Wangari, 2008). As a result most NEPAD schools restricted students' use of the NEPAD ICT laboratory. It was no wonder only 53 percent of all students used Internet services. The restriction seemed unfair yet necessary (Pring, 2009) as it also served to help teachers control the sites learners were accessing (Ruhe \& Zumbo, 2009). The study results further indicated that e-libraries were only present in the NEPAD schools except for one non-NEPAD school. Yet it is a fact that education research becomes quite simple if electronic content (e-content) is available (Allen, 2003; "Online learning," 2008). An investigation of the presence of e-libraries was necessary because their presence would enable teachers in the schools to train their learners in personal study through research. In this way the schools would have teachers and learners who are in a position to use electronic materials in research and personal study. The results indicated that the NEPAD schools had a total of 40 e-libraries spread amongst them. This gave them an average of at least six e-libraries in each school. The checklist further revealed that one of the NEPAD schools had a total of 15 different e-libraries down loaded on their computers. The checklist revealed further that the main e-libraries in the NEPAD schools were Mindset, Encarta, Wikipedia, and Health Matters, which students used for personal information search as they studied, a fact supported by Mason and Rennie (2008), Chapel (2009), and Kioni (2009). In the non-NEPAD schools, on the other hand, there were only three e-libraries. All the three were available in only one school, meaning that all the other five schools had none at all. This one school had its ICT programme funded by an external donor unlike the others that were funded either by the Boards of Governors (BOG) or Parents Teachers Associations (PTA). Therefore it could be concluded that e-libraries were expensive and as such out of reach to schools whose only funding of the ICT project was BOG/PTA. This came out clearly because the schools' PTA/BOG could afford to invest in computers (averagely 24 per non-NEPAD and 46 per NEPAD School) but were not able to invest in even a single e-library. This fact was true for both categories of schools except in one school that had more e-materials than what NEPAD had provided, meaning the BOG/PTA sourced for or bought the rest. This suggested that besides prohibitive costs, the other possible explanation for BOG/PTA's lack of investment in e-libraries was lack of information on the same (Kioni 2009). This was because the only school that had extra elibraries other than what NEPAD had provided had a very aggressive ICT HOD who took personal initiative to provide information needed for further ICT use in the school. This came out when the checklist indicated that it was the only school that had networked its ICT operations such that the principal could access all school records from his office (Ritz, 2009). The same school offered peer training to other teachers in the whole province on ICT integration while the students were able to give clear presentations on any subjects of their choice using ICT appliances. It meant that this particular school had attained a level of implementation of ICT education that the other NEPAD schools had not yet embarked on. This brought out the fact that ICT integration requires personal initiative and interest amongst the teachers to drive its cause (Bus \& Neuma, 2009; Government of Kenya [GOK], 2009; "Online learning," 2008,). The situation is changing for most Kenyan schools as the government has undertaken initiatives to ensure all schools will have access to digital content. The main curriculum development body (Kenya Institute of Education) has digitized the entire curriculum from nursery to secondary level (GOK, 2009; Ongeri, 2009). This has led to most publishers providing a digital version of their books (Bus \& Neuma, 2009; Ongeri, 2009) and has made the government to introduce mobile digital libraries in all the constituencies (GOK, 2009). Email usage by students was mainly indicated in the NEPAD schools (91\%). Further investigation revealed, though, that this was used mainly for personal communication and not for educational purposes. This fact however is good because later on as the different schools become networked (Chapel, 2009; Kioni, 2009; Tilvawala et al., 2009) learners will be able to share academic content with each other.

The study result further indicated that NEPAD schools performed much better than the nonNEPAD schools both in the KCSE Computer Studies as well as the overall KCSE mean grade 
even though the difference in performance was not significant. This was the main expectation that made governments embrace the NEPAD project fully (Ogule, 2009; Patterson, Oruko, \& Okwatch, 2009). This was because technology was expected to improve classroom delivery, create learner motivation in classroom tasks, increase access and interaction, and improve the information base of both teachers and learners (Chou, Hooft, \& Lin, 2008; Frederick \& Shockley, 2009; Gobbo \& Girardi, 2001; Komba, 2009; McCarthy \& Berger, 2008). The findings of this research were in line with the results reported from Batchelor et al. (2003, p. 126) of schools where elearning had been practiced: "There has been a revolution: we have better facilities to engage in dialogue and to solve problems that emerge in the classroom, and also to create projects to address our local needs." A student stated, "The classes were tedious, full of books and notebooks, working individually without integration of materials. Now we work in groups, everyone values the work of all members of the class, there is communication with companions in other schools, and the teachers are more dynamic. Now the learning activities challenge your own creativity and it is more fun to work in the classroom." Another study reported by AbdulSamad (2006) and Tilvawala et al. (2009) gave a discourse of the successful implementation of e-learning by NEPAD in a primary school in Coast province, Kenya. This was the very first primary school in the whole of Africa to join the NEPAD programme. The admission of the primary school and the success stories behind its e-learning implementation gave hope for the eventual ICT implementation in all the sectors of education in Kenya as was confirmed for secondary schools in this study.

Lastly, the main factors that influenced learners' ICT application in this study were availability of computers; rules and regulations from the ICT department; number of computer literate teachers in the school; school rules and regulations; school administration's policy on computer use; regulations from the ICT funding bodies; and the daily schedule of the school. These findings were in line with those from other studies. For example, Brown (2009) and Sahlfeld (2009) both agreed that availability of a good variety of reliable ICT equipment enhanced learners' ICT competencies and literacy. Gobbo and Girardi (2001), Ritz (2009), and Sang et al (2009) all indicated that teachers' ICT literacy level influenced how learners used ICT in a school. Zhao and Bryant (2009) in their study found out that besides teachers' ICT literacy level, availability of ICT support staff improved learner's competencies and ICT usage. It was noted in this study that there was total lack of ICT support staff in all the study schools. It could therefore be stated that this affected the learners negatively since the ICT laboratory remained closed once the teachers were busy elsewhere. Friesen (2009) noted that school rules and regulations affected the ICT components learners were allowed to access. At the same time, McCarthy and Berger (2008) further indicated that a school's ICT policy greatly affected whether a student chooses to pursue studies in technology.

\section{Conclusion}

From the study, it was noted that the NEPAD schools had teachers with better professional qualification, higher computer literacy ratios, and higher computer staffing levels than the teachers from non-NEPAD schools. At the same time, teachers from NEPAD schools benefited more from in-service training in ICT especially because of the peer-training concept practiced, which was lacking in non-NEPAD schools. The study also noted that none of the study schools employed an ICT technician nor did they receive any funding from the government for technical assistance. Instead the BOGs and the PTAs sourced and paid for technical assistance as the need arose.

Integration of ICT in other subject areas was an on-going process in NEPAD schools. This was because specific results indicated that there was a significant difference in the use of ICT in teaching Humanities, Languages, and Mathematics in NEPAD and non-NEPAD schools. Their use in Science was not significantly different because usage was common in both categories of schools. Furthermore, the presence of free Internet connectivity and modern ICT equipment in the 
NEPAD schools were the factors that made NEPAD schools significantly better in their use of ICT facilities in the teaching/learning process. This was because it made education research and ICT integration in the curriculum subjects possible. Besides integration, the availability of ICT programmes in both the NEPAD and non-NEPAD schools resulted in improved administrative services in the schools.

The NEPAD schools had a wider variety and higher quantity of ICT equipment and materials. This resulted in wider application and better access to online materials by students in the NEPAD schools compared to those from non-NEPAD schools. The presence of the Internet and e-libraries in the NEPAD schools resulted in significant differences in ICT application areas in NEPAD and non-NEPAD schools. As a result the students in the NEPAD schools posted significantly higher mean grades in the KCSE examinations than those from the non-NEPAD schools.

The three main factors that affected students' use of the ICT facilities in the computer laboratory were the number of computers in a school, rules and regulation from the ICT department, and the number of computer literate teachers in the school.

From the research results, the researchers suggested that each school should develop an ICT policy in line with the Ministry of Education policy targeting complete curriculum reforms, Instructional reforms, Assessment reforms, Teacher development, School organisation and administration, and Community participation/partnership development in the ICT programme.

\section{Recommendations from the Research}

The following are some of the recommendations the researchers hope could help improve the state of ICT education in secondary schools in Kenya from facts noted during the study:

Any school offering ICT education should employ an ICT technician who could make the computer laboratory accessible to learners all the time, much like a school library, and to be able to repair the hardware.

The government should provide in-service training to key resource teachers at least once in a year. These teachers would then introduce peer training in their schools as this would enhance other teachers' ability to integrate ICT in their teaching subject and as a result make them more innovative in their use of ICT as a tool in the teaching/learning process. In this way learners would perceive ICT as a useful tool in learning and as a result enlarge their e-learning capabilities. At the same time teachers would find an avenue to share new skills and knowledge with each other.

The school BOGs, with assistance from the government, should look for private sector partners who would be able to install Internet facilities and e-libraries for the public schools having ICT facilities to enhance and improve learners' personal information base. This would assist the government in achieving their objective of making "education the natural platform for equipping the nation with ICT skills" (GOK 2009).

The government, with the help of NEPAD, should set up ICT laboratories in each educational division in the country to serve as a learning resource center to all learning institutions and the community in that division. This would provide ICT resources to the community and, in particular, the teaching fraternity in that locality. They could be encouraged to make monthly membership subscriptions, which to a small extent could subsidize the maintenance of the facilities. In this way, information would be available to teachers and the wider community through the Internet and e-libraries even in the rural areas where the majority of the population may not be able to afford such facilities in their schools or homes. 
Local software companies could liaise with the education sector policy makers to provide country and curriculum specific software relevant to the needs of the nation. These companies could offer, for instance, to forward personnel to the KIE to fast track their change of curriculum content to econtent.

School ICT laboratories should be located in such places as would allow the community to access the facility without being a security risk to other infrastructure in the school. This would mean enough reinforcement and external security arrangements with the community and the building being closer to the outer gates so that outsiders could access it without necessarily getting into the school compound.

\section{References}

AbdulSamad, A. (2006, July 9). Rural school set pace in IT. Daily Nation Newspaper, p. 23.

Allen, M.W. (2003). Guide to e- learning: Building interactive, fun and effective learning program for any company. New Jersey: John Wiley and Sons.

Allison, S., \& Harbour, M. (2009). The coaching toolkit. London: Sage.

Avgerou, C. (2008). Information systems in developing countries: A critical research review. Journal of Information Technology, 23,133-146.

Batchelor, S., Evangelista, S., Hearn, S., Pierce, M., Sugdem, S., \& Webb, M. (2003). ICT for development: Contribution to the millennium development goals. Washington: InforDev.

Batchelor, S., \& Nocrish, P. (2005). Framework for assessment of ICT pilot project: Beyond monitoring and applied research. Washington: InfoDev.

Bonyo, J. (2008, September 16). Zain launches internet plan for schools. Daily Nation Newspaper, p. 4.

Brown, R. A. (2009). Curriculum consonance and dissonance. Journal of Technology Education, 20(4).

Bus, A., \& Neuma, S. B. (2009). Multimedia and literacy development. New York: Routledge.

Chapel, W. (2009, November 27). Teachers begin using cell phones for class lessons. Associated Press. Retrieved November 27 from http://tech.yahoo.com/news/ap/20091127/ap on hi te/us schools cell phones

Chou, C. C., Hooft, M. V., \& Lin, Y. (2008). Engaging diverse secondary students in international collaborative networked learning. Journal of Educational Technology Development and Exchange, 1(1), 4154 .

Eunjoo, O., \& French, R. (2004). Pre-service teachers' perception of an introductory instructional technology course. Electronic Journal for the Integration of Technology in Education. Retrieved on November 23 from http://ejite.isu.edu/Archive.html

Farrell, G., Isaacs, S. \& Trucano, M. (2007). The NEPAD e-schools demonstration project: A work in progress. A public report. Washington: InfoDev.

Frederick, R., \& Shockley, K. (2009). A portrait of three teachers working in urban schools. Electronic Journal for the Integration of Technology in Education, 7, 3-21. Retrieved on November 23 from http://ejite.isu.edu/Archive.html

Friesen, N. (2009). Rethinking e-learning research. New York: Peter Lang.

Gall, M. D., Borg, W. R., \& Gall, J. P. (1996). Educational research: An introduction (6 ${ }^{\text {th }}$ ed.). New York: Longman.

Garvey, B. (2009). Coaching and mentoring: Theory and practice. London: Sage.

Gay, L. R. (1996). Educational research: Competences for analyses and application (5th ed.). New Jersey: Prentice Hall. 
Geisert, P. G. \& Futrell, M. K. (2000). Teachers, computers and curriculum: Microcomputers in the classroom (3rd ed.). Boston: Allyn and Bacon.

Gobbo, C., \& Girardi, M. (2001). Teachers' beliefs and integration of information communication technology in Italian schools. Journal of Technology, Pedagogy and Education, 10 (1\&2), 63-85.

Government of Kenya. (2009). The economic stimulus programme. Nairobi: Government Printers

Hinterberger, H. (2009). E-learning: Make it simple as possible, but not simpler. ATDF Journal, 4(2), 1118.

ICT set up in schools remains a pipe dream. (2006). Education Insight. (09). Nairobi: Image Books.

LaPorte, J. (2008). Branding the horse we are going to ride into green pastures ahead. Journal of Technology Education, 19 (2).

Kioni, M. (2009, December 9). Investing in ICT education for the next generation. ICT and security. The Standard Newspaper. Nairobi: KTN Media.

Kinyanjui, R., \& Ndiritu, A. (2005). Importance of ICT integration. A paper presented in an ICT workshop held at Bondo T. T. C. on August $29^{\text {th }}-3^{\text {rd }}$ September, 2005.

Krige, K., \& Okono, P. (2007, May). Setting up and sustaining e-learning projects. A paper presented at the $2^{\text {nd }}$ International Conference on ICT for Education and Training at the Safari Park Hotel, Nairobi, Kenya.

Komba, W. L. M. (2009). Increasing education access through open and distance learning in Tanzania: A critical review of approaches and practices. International Journal of Education and Development Using ICT, 5(5).

Ma, Y., Lai, G., Williams, D. C., \& Prejean, L. (2008). Teachers' belief changes in a technology enhanced pedagogical laboratory. Journal of Educational Development and Exchange, 1(1), 15-28.

Mason, R., \& Rennie, F. (2008). E-learning and social networking handbook. London, UK: Routledge.

McCarthy, R. R., \& Berger, J. (2008). Moving beyond cultural barriers: Successful strategies of female technology education teachers. Journal of Information Technology 23, 133-149.

McNamara, K. S. (2003, December). Information and communication technologies, poverty and development: Learning from experience. A background paper for infoDev Annual Symposium.

Ministry of Education. (2006). National information and communication technology (ICT) strategy for education and training. Nairobi: Government Printers.

MOEST. (2005). Sessional Paper No.1 of 2005 on Policy Framework for Education, Training and Research. Nairobi: Government Printers.

NEPAD. (2005). A NEPAD e-Africa Commission Initiative for Africa. Nairobi: NEPAD e- Schools, Kenya.

Odera, F. Y. (2002). A study of computer integrated education in secondary schools in Nyanza Province, Kenya. Unpublished PHD Thesis, University of Pretoria, South Africa.

Ogule, P. A. (2009). The evaluation experience of primary and secondary education in Kenya. Nairobi: CUEA.

Okuogo, G. (2006, November 6). Bridging the digital divide: Options available for the ICT uptake in Kenya. ICT Journal: Daily Nation Newspaper, p. v.

Okutta, M. (2007. February 11). Boost to digital village initiative. The Sunday Standard Newspaper, p. 3.

Ongeri, S. (2009, December 10). Here comes e-Books. The Standard Newspaper, p. 14.

Online learning. (2008). In Wikipedia. Retrieved November 29 from http://en.wikipedia.org/wiki/Online learning 
Oracle Corporation. (2005). Launch of NEPAD e-schools. Nairobi: NEPAD e- Schools Commission.

Oriwo, M. O. (2002). The professional teachers' guide. Malindi: Key Press Publishers.

Orodho, A. J. (2004). Elements of education and social science: Research methods. Nairobi: Masola Publishers.

Paechter, M., Maier, B., \& Macher, D. (2009). Student expectation of and experiences in e-learning: Their relation to learning achievement and course satisfaction. Journal of Computers and Education 54, 222229. Retrieved on 26/11/09 at www.elsevier.com/locate/come

Patterson, F., Oruko, J., \& Okwatch, T. (2009, May). Expectation of government in e-learning project. Elimu News, p. 23.

Pring, R. (2009). Education for all. New York: Routledge

Ritz, J. M. (2009). A new generation of goals for technology education. Journal of Technology Education, $20(2)$.

Rodrigo, M. M. T. (2003). Tradition or transformation? An evaluation of ICTs in Metro Manila schools. Journal of Information Technology for Development 10(2), 95-122.

Ruhe, V., \& Zumbo, B. D. (2009). Evaluation in distance education and e-learning. NewYork: Guildford Press.

Sadker, M. P., \& Sadker, D. M (2000). Teachers, schools, and society New York: McGraw Hill.

Sahlfeld, M. (2009). How does ICT work for development? A review of challenges and opportunities. ADTF Journal, 4 (1), 22-36.

Sang, G., Valcke, M., Braak, J. V., \& Tondeur, J. (2009). Student teachers' thinking processes and ICT integration: Predictors of prospective teaching behaviour with educational technology. Computers and Education Journal, 54(1), 103-112.

Schifter, C. C. (2008). Infusing technology into the classroom. Hershey: IGI Global.

Schrum, L., \& Dehoney, J. (1998). Meeting the future: A teacher education program joins the information age. Journal of Technology and Teacher Education, 6(1) 23-37. Retrieved on September 10, 2006 from http://www.aace.org/pubs/jtate/

Tilya, F. N. (2007). Policy issues in ICT education and training. Retrieved July 1 from http://iucea.org/downloads/4.\%20Policy\%20Issues\%20in\%20ICT\%20Education\%20and\%20Training. $\underline{\text { doc }}$

Tilvawala, K., Myers, M. D., \& Andrade, A. D. (2009). Information literacy in Kenya. Electronic Journal of Information Systems in Developing Countries, 39. Retrieved November 23 from http://www.ejisdc.org/ojs2

Wafula, J. M., \& Wanjohi, N. (2007). Kenya ICT policy draft document. Nairobi: IDRC.

Wangari, V. (2008, May 21). E-learning still a pipe dream for public schools. The Standard News Paper, p. 8.

Weiner, A., \& Rumiany, D. (2007). A new logic of reducing the global digital divide in sub-saharan Africa: From obstacles to opportunities. ADTF Journal, 4(1), 14-21.

Zhao, Y., \& Bryant, F. L. (2009). Can teacher technology training alone lead to high levels of technology integration? A qualitative look at teacher technology integration after state mandated technology training. Electronic Journal for the Integration of Technology in Education, 5, 54-62 


\section{Biographies}

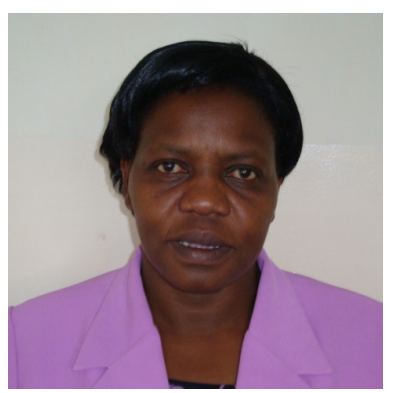

Mildred A. Ayere is a lecturer in the Department of Educational Technology and Curriculum Studies, Maseno University. She teaches Educational Media and Resources, General Methods of Teaching, Mathematics Education and other Educational Technology courses. Earlier on, she worked as a high School teacher, a college tutor and a staffing officer with the Teacher's Service Commission. In addition to her teaching experience, she is an entrepreneur in teacher education. Her primary research interests include ICT integration in pedagogy and teacher centred methodologies in mathematics.

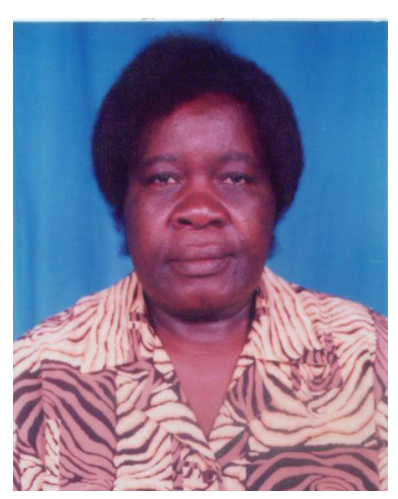

Florence Yukabet Odera is a Senior lecturer in the School of Education \& Social Sciences at Bondo University College. Her research focuses in Education, Educational Technology (the use of computer technologies in teaching and learning) and Instructional Strategies that stretcher back to 1970 s. She is now conducting a study on the history of Education Technology in Kenyan Education. Dr Odera holds a PhD in Curriculum Instruction (Use of Computers in teaching and learning), MPhil degree in Educational Broadcasting from the University of Wales Aber, MA \& BA Educational Studies from Hull University (Address: Dr. Florence Odera. P.O. Box 2303, Kisumu, Kenya: E.mail: Odera_florence@yahoo.co.uk.)

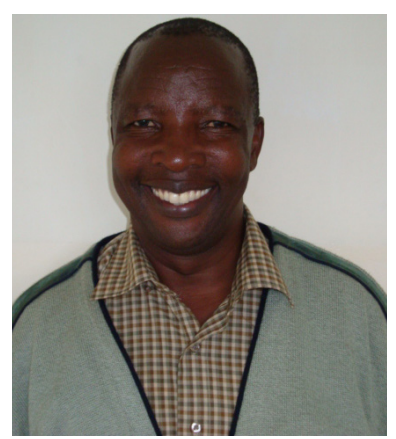

Professor John Odwar Agak is a professor of Psychology in Maseno University, Kenya. He specializes in psychometrics, and lectures in Research Methodology, Intentional Interviewing, and Group Psychology courses at the postgraduate level. He has publications in the areas of vocational and technical education, pedagogy, curriculum development, educational technology, special needs education, educational evaluation and psychology. He has also published written several books in Education. He has worked in the same University for the last twenty years and has supervised many postgraduate students at Masters and Doctor of Philosophy Degree levels as well as serving in a number of administrative posts. 